УДК 349.22

DOI https://doi.org/10.32837/pyuv.v0i2(31).565

\author{
Ю. І. Марченко \\ orcid.org/0000-0002-4797-8511 \\ здобувач кафедри правознавства \\ юридичного факультету \\ Східноукраїнського національного університету імені Володимира Даля
}

\title{
ГІДНА ОПЛАТА ПРАЦІ - НЕОБХІДНИЙ АТРИБУТ СОЦІАЛЬНОЇ ДЕРЖАВИ
}

Постановка проблеми. Ст. 1 Основного Закону країни проголошено, що Україна є суверенною і незалежною, демократичною, соціальною, правовою державою. Людина, її життя і здоров'я, честь і гідність, недоторканість і безпека визнаються в Україні найвищою соціальною цінністю. Права і свободи людини та їхні гарантії визначають зміст і спрямованість діяльності держави, яка відповідає перед людиною за свою діяльність. Утвердження і забезпечення прав і свобод людини є головним обов'язком держави (ст. 3) [1]. Важливе місце в системі конституційних прав людини та громадянина посідають соціально-економічні права та свободи у сфері власності, підприємництва, праці, відпочинку, соціального захисту, охорони здоров'я, які дають можливість людині задовольняти свої потреби й інтереси, а також визнаються суспільством, державою та міжнародною спільнотою. Провідна роль серед соціально-економічних прав людини належить праву на оплату праці, завдяки якому людина забезпечує існування себе та своєї сім'ї. Так, ч. 4 ст. 43 Конституції України закріплюється право на заробітну плату, не нижчу за визначену законом, а ч. 7 гарантовано, що право на своєчасне отримання винагороди за працю захищається законом. У самому змісті права на оплату праці проголошено, що кожен має право на оплату праці, яке включає можливість заробляти собі на життя працею. Тобто для того, щоб забезпечити собі та своїй родині гідне життя, людина повинна працювати та залежно від свого внеску в трудову діяльність отримувати винагороду - заробітну плату. Тільки через гідну оплату праці й удосконалення механізму її регулювання можна рухатися вперед шляхом прогресу і процвітання держави.

Мета статті. У розрізі вищенаведеної проблематики розглянути гідну оплату праці як шлях до розвитку економіки та зростання трудових доходів зайнятого населення.

Аналіз останніх досліджень i публікацій. Правовим засадам реалізації права на оплату праці приділялася увага в роботах таких науковців, як В. Божко, Н. Болотіна, В. Вегера, Ю. Верес, О. Гаєва, Н. Гетьманцева, К. Довбиш, О. Процевський, К. Севастьяненко, О. Соколова, Н. Хуторян, Г. Чанишева, О. Ярошенко та ін.
Окремі аспекти концепції гідної праці розглядалися у дослідженнях фахівців у галузі трудового права М. Маковецької, Г. Капліної, Т. Коляди, Л. Костіної, К. Теличко та ін.

Виклад основного матеріалу. У соціально-економічному розвитку будь-якої сфери економічної діяльності важливу роль відіграє оплата праці, яка належить до фундаментальних складників умов трудової діяльності працівників. Саме заробітна плата визначає найбільш вагомі параметри умов праці, тому найважливішою складовою частиною концепції гідної праці є забезпечення справедливої та задовільної винагороди за трудову діяльність найманих працівників, що має забезпечуватися інструментами державної соціальної політики [2]. Ст. 2 КЗпП України закріпила як принцип трудового права України право кожного працівника на одержання роботи з оплатою праці не нижчою за встановлений державою мінімальний розмір. Держава надає мінімальному розміру оплати праці значення соціального стандарту, функція якого полягає в тому, щоб забезпечити відповідно до зобов'язань, взятих на себе за Міжнародним пактом про економічні, соціальні та культурні права, реалізацію кожним працівником права на гідний життєвий рівень [3, с. 287].

Концепція гідної праці відображена у міжнародних нормах, що стосуються прав людини та соціально-трудової сфери. Так, у Загальній декларації прав людини проголошено: «Кожен працюючий має право на справедливу і задовільну винагороду, яка забезпечує гідне людини існування, ï самої та її сім'ї та яка в разі необхідності доповнюється іншими засобами соціального забезпечення». Тобто в цьому положенні метою заробітної плати $€$ забезпечення гідного існування людини та її сім'ї.

Важливе значення для громадян України мають акти Європейського Союзу щодо гарантій права людини на працю після того, як Україна проголосила курс на членство в СС і підписала в 2014 р. Угоду про асоціацію України з Свропейським Союзом. Провідне місце в гарантуванні права людини на працю в ЄС посідає Хартія Співтовариства про основні соціальні права працівників, прийнята Главами держав або урядів держав - членів Свропейського Співтовариства на зустрічі у Страсбурзі 9 грудня 1989 р. Головною метою прийняття Хар- 
тії Співтовариства про основні соціальні права працівників було сприяння поліпшенню життя й умов праці працівників. За ст. 4 Хартії Співтовариства про основні соціальні права працівників кожна особа вільна обирати та працювати за спеціальністю відповідно до регламентів, що регулюють кожний вид діяльності. А ст. 5 цього документа гарантовано, що всі види зайнятості підлягають справедливій винагороді. Із цією метою згідно $з$ положеннями, які застосовуються в кожній країні, працівникам забезпечується справедлива заробітна плата, тобто заробітна плата, достатня для забезпечення їм гідного рівня життя; відповідно до умов зайнятості працівники, крім тих, що працюють на основі безстрокового контракту на умовах повного робочого часу, отримують пропорційну винагороду; заробітна плата може бути утримана, вилучена або передана лише відповідно до національного законодавства. Подібні положення мають передбачати заходи, які дають змогу зацікавленому працівникові продовжувати користуватися необхідними засобами існування для нього та його сім'ї [4].

Значну увагу запровадженню концепції гідної праці та заробітної плати приділяє Міжнародна організація праці. У пілотній програмі МОП із реалізації концепції гідної праці термін «гідна праця» визначається як «праця, яка приносить адекватний дохід і залишає час для інших сторін життя, надає надійність сім'ї, шанує права людини, надає право голосу і відкриває дорогу соціальній інтеграції. Гідна праця - це шлях, що сполучає економічні та соціальні цілі» [5]. МОП сприяє запровадженню принципів гідної праці в Україні. Так, у квітні 2016 р. Україна і МОП підписали Меморандум про взаєморозуміння щодо реалізації Програми гідної праці для України на період 2016-2019 pp. [6], у якій значна увага приділена висвітленню проблем оплати праці в Україні. Зокрема, головна мета Програми - забезпечення повної, продуктивної, безпечної зайнятості з гідною оплатою праці шляхом реалізації спільних дій соціальних партнерів, з одного боку, та Міжнародної організації праці - з іншого. У Програмі відзначається, що заохочення гідної праці є ключовим компонентом політики й основним завданням соціальних партнерів. Ця програма гідної праці передбачала, що Міжнародна організація праці продовжить надання Україні технічної допомоги для досягнення повної зайнятості населення шляхом розвитку малого і середнього бізнесу та підвищення рівня кваліфікації зайнятих людей, що забезпечить розвиток економіки та зростання трудових доходів зайнятого населення.

Як бачимо, міжнародні договори є одним із найбільш дієвих інструментів забезпечення реалізації конституційного права людини на оплату працю в Україні, в них установлюються важли- ві гарантії реалізації цього права, а також дієві шляхи його захисту. Встановлені в міжнародних актах стандарти реалізації права на оплату праці є загальноприйнятими міжнародним співтовариством вимогами до всіх країн щодо забезпечення свободи праці, належних, безпечних і здорових умов праці, гідної винагороди, рівності прав чоловіків і жінок у сфері праці, а також судового захисту й інших гарантій.

Як зазначає Т.А. Коляда, проаналізувавши міжнародні нормативно-правові акти та нормативно-правові акти національного трудового законодавства, концепція гідної праці спрямована на забезпечення високого рівня і якості життя людини, що характеризуються добробутом, доступністю соціальних благ, соціальним статусом у рамках стратифікації суспільства. Концепція гідної праці охоплює чотири компоненти, а саме: зайнятість, права, захист, діалог. Зайнятість передбачає гідну оплату праці (гідні засоби існування), справедливі та безпечні умови праці, охорону здоров'я і праці на робочому місці, доступність продуктивної та значимої праці, перспективи особистісного розвитку. Права працівників у сфері зайнятості передбачають наявність розвиненого трудового законодавства, що грунтується на принципі верховенства права, а також охоплюють право об'єднань, право слова, право на професійну освіту і профорієнтацію, Іендерну рівність, право ведення колективних переговорів, відсутність будь-яких форм дискримінації, примусової та дитячої праці. Соціальний захист має забезпечувати інтереси працівників у разі втрати або зниження доходів через безробіття або травмування, передбачає право на соціальне, медичне та пенсійне страхування і забезпечення. Соціальний діалог зумовлює можливість представництва працівників і роботодавців на рівні певних організацій, а також спільного пошуку й ухвали рішень у разі виникнення виробничих конфліктів [7].

У наукових джерелах також приділяється увага цій проблематиці, однак існують різні підходи до розуміння цього явища. Одні вчені під гідною заробітною платою розуміють такий її рівень, що здатен забезпечити економічну свободу працюючій людині та її сім’ї; створює базові основи для систем соціального страхового захисту і соціального забезпечення; дає можливість людині розвиватися, відпочивати, користуватися досягненнями цивілізації, відповідає поняттю справедливого розподілу результатів праці; заробляється в умовах, які не принижують гідність людини; вирішує проблему матеріальної бази для розширеного відтворення населення країни, забезпечення економіки кваліфікованими трудовими ресурсами [8]. Інші пропонують категорію «гідна оплата праці» розглядати у двох аспектах: 1) як певний рівень оплати праці окремих працівників, що забезпе- 
чує нормальне відтворення робочої сили та можливості розвитку людського потенціалу родини працівника, є адекватним його трудовим зусиллям і здобутій кваліфікації; 2) як відповідну систему оплати праці, яка забезпечує дотримання соціально-трудових прав найманих працівників, є справедливою та здійснюється з використанням сучасних досягнень організації заробітної плати на підприємствах і в установах.

До основних параметрів системи гідної оплати праці запропоновано віднести: а) достатній рівень заробітної плати для задоволення дійсних потреб працівника та його родини, що забезпечує розширене відтворення населення і робочої сили, стимулює до ефективної праці та професійного зростання; б) забезпечення поступового зростання номінальної заробітної плати на основі підвищення продуктивності праці й ефективності організації виробництва; в) підтримку реального рівня заробітної плати та забезпечення його зростання, недопущення зниження купівельної спроможності; г) неухильне дотримання законодавства в організації оплати праці, забезпечення офіційної виплати її повного обсягу без тіньової складової частини; д) відповідність розміру заробітної плати обсягам і складності виконаної роботи, рівню кваліфікації працівника; е) своєчасну виплату заробленого трудового доходу, недопущення заборгованості з оплати праці; є) прозору та зрозумілу систему організації оплати праці, прийнятну (допустиму) міжпосадову i міжгалузеву диференціацію рівня заробітної плати; ж) застосування сучасних прогресивних форм і систем оплати та стимулювання праці, механізмів соціального партнерства в організації заробітної плати [2, с. 8].

Сьогодні можна стверджувати, що в нашій державі реалізується концепція гідної оплати праці - право кожного на винагороду за працю без дискримінації та не нижчу за встановлену за мінімальний розмір праці. Водночас ця концепція спрямована не на забезпечення життя, а швидше на «виживання». 3 цих позицій є актуальним закріплення у вітчизняному законодавстві поняття «гідна оплата праці», характерними рисами якої є: рівень заробітної плати, відповідність світовим стандартам, вартості життя та робочої сили; справедлива заробітна плата щодо інших працівників; відповідність заробітної плати кількості та якості праці; своєчасна виплата.

Висновки. Підтримуючи позиції інших дослідників цієї проблематики, можемо констатувати, що інститут оплати праці є одним із основних інститутів трудового права, спрямованих на забезпечення права працівників на гідне життя. Заробітна плата є провідним інструментом соціальної політики, яка зумовлює рівень соціальності суспільства, здатності держави підтримувати рівень якості життя соціуму загалом і кожної людини зокрема. Держава виступає гарантом реалізації права на оплату праці. Переконані, що запровадження в Україні концепції гідної заробітної плати необхідне та вигідне для всіх суб'єктів економічної діяльності: для найманих працівників, котрі за рахунок цього зможуть отримати достатні кошти для задоволення своїх потреб, можливостей людського розвитку та забезпечення високої якості життя і суспільного статусу; для роботодавців, для яких гідна оплата праці сприятиме формуванню висококваліфікованого кадрового ядра, підвищенню якості та продуктивності праці, лояльності персоналу, розвитку соціального партнерства та підвищенню конкурентоспроможності; для держави запровадження гідної оплати праці забезпечить зростання рівня та якості життя населення, формування середнього класу, підвищення рівня соціальної стабільності в суспільстві, розширення ємності внутрішнього ринку.

\section{Jimepamypa}

1. Конституція України від 28 червня 1996 р. № 254к/96-ВР. Відомості Верховної Ради України. 1996. № 30. Ст. 141.

2. Антонюк В.П. Соціальна політика у сфеpi оплати праці: проблеми та шляхи забезпечення iii гідного рівня (на прикладі промисловості). URL: http://dspace.nbuv.gov.ua/bitstream/handle/ 123456789/127391/1-Antonyuk.pdf?sequence=1.

3. Гетьманцева Н.Д., Козуб І.Г. Трудове право України (Особлива частина). Чернівці, 2014. 503 с.

4. Хартія Співтовариства про основні соціальні права працівників від 09 грудня 1989 p. URL: https://zakon.rada.gov.ua/laws/show/994_044.

5. Международная организация труда: конвенции, документы, материалы : справочное пособие / под ред. 3.С. Богатыренко. Москва : Изд-во "Дело и сервис», 2011. $752 \mathrm{c}$.

6. Україна і МОП підписали Меморандум про взаєморозуміння щодо реалізації Програми гідної праці для України на період 2016-2019 роки. URL: https://www.kmu.gov.ua/news/248947884.

7. Коляда Т.А. Концепція гідної праці у трудовому праві України. Форум права. 2010. № 3. URL: file:///C:/Users $/ \%$ D0 $\%$ 90 $\%$ D0 $\%$ B $4 \%$ D0 $\%$ BC $\%$ D0 $\%$ B8 $\%$ D0 $\%$ BD $\%$ D0 $\%$ B8 $\%$ D1 $\% 81 \%$ D1 $\% ~ 82 \%$ D1 $\% ~ 80 \%$ D0 $\%$ B0 $\%$ D1 $\% 82 \%$ D0 $\%$ BE $\%$ D1 $\%$ 80/Downloads/FP index.htm_2010_3_29.pdf.

8. Капліна Г.А. Характеристика концепції гідної праці в Україні. Актуальні проблели права: теорія $i$ практика. 2013. № 26. С. 47-54.

\section{Анотація}

Марченко Ю. І. Гідна оплата праці - необхідний атрибут соціальної держави. - Стаття.

У статті розглянуто гідну оплату праці як шлях до розвитку економіки та зростання трудових доходів зайнятого населення. Зазначено, що інститут оплати праці є одним із основних інститутів трудового права, спрямованих на забезпечення права працівників на гідне життя. Заробітна плата є провідним інструментом соціальної політики, яка зумовлює рівень соціальності суспільства, здатності держави підтримувати рівень якості життя соціуму загалом і кожної людини зокрема. Держава виступає гарантом реалізації права на оплату праці. Міжнародні договори є одним із най- 
більш дієвих інструментів забезпечення реалізації конституційного права людини на оплату працю в Україні, в них установлюються важливі гарантії реалізації цього права, а також дієві шляхи його захисту.

Зроблено висновок, що запровадження в Україні концепції гідної заробітної плати необхідне та вигідне для всіх суб'єктів економічної діяльності: для найманих працівників, які за рахунок цього зможуть отримати достатні кошти для задоволення своїх потреб, можливостей людського розвитку та забезпечення високої якості життя і суспільного статусу; для роботодавців, для яких гідна оплата праці сприятиме формуванню висококваліфікованого кадрового ядра, підвищенню якості та продуктивності праці, лояльності персоналу, розвитку соціального партнерства та підвищенню конкурентоспроможності; для держави запровадження гідної оплати праці забезпечить зростання рівня та якості життя населення, формування середнього класу, підвищення рівня соціальної стабільності в суспільстві, розширення ємності внутрішнього ринку.

Запропоновано закріпити у вітчизняному законодавстві поняття «гідна оплата праці», характерними рисами якої мають бути: відповідність світовим стандартам, вартості життя та робочої сили; справедлива заробітна плата щодо інших працівників; відповідність кількості та якості праці; своєчасна виплата.

Ключові слова: працівник, соціальна, держава, гідна оплата праці, національне законодавство, міжнародні норми.

\section{Summary}

Marchenko Y. I. Decent wages - a necessary attribute of the welfare state. - Article.

The article considers a decent wage as a way to economic development and growth of labor income of the employed population. It is noted that the institution of wages is one of the main institutions of labor law, aimed at ensuring the right of workers to a dignified life. Wages are the leading instrument of social policy, which determines the level of sociality of society, the ability of the state to maintain the quality of life of society, including everyone. At the same time, the state acts as a guarantor of the right to remuneration. It is emphasized that international agreements are one of the most effective tools for ensuring the implementation of the constitutional human right to remuneration in Ukraine, they establish important guarantees for the implementation of this right, as well as effective ways to protect it.

It is concluded that the introduction of the concept of a decent wage in Ukraine is necessary and beneficial for all economic entities: for employees who will be able to obtain sufficient funds to meet their needs, human development opportunities and ultimately - to ensure high quality. life and social status; for employers for whom a decent salary will contribute to the formation of a highly qualified staff, improve the quality and productivity of labor, staff loyalty, the development of social partnership and increase competitiveness; for the state - the introduction of decent wages will increase the level and quality of life of the population, the formation of the middle class, increase the level of social stability in society, expand the capacity of the domestic market.

It is proposed to enshrine in domestic legislation the concept of "decent wages", the characteristics of which should be: the level of wages meets world standards, cost of living and labor; fair wages to other employees; wages correspond to the quantity and quality of labor; wages are paid on time.

Key words: worker, social, state, decent pay, national legislation, international norms. 